\title{
Perspectives of Romanian accounting professionals on Integrated Reporting
}

\author{
Ioana Sofian (Neacșu) $)^{1, a}$ \\ ${ }^{\text {a }}$ Romania
}

\begin{abstract}
Research question: Are Romanian accounting professionals able to face the challenges of integrated reporting?

Motivation: Human beings are present in each phase of implementing integrated reporting and/or preparing the integrated report. In other words, the evolution of integrated reporting relies very much on the humans' subjectivity and interaction. Idea: This paper aims to identify the perspectives of Romanian chartered accountants and financial auditors on the concepts of integrated reporting and integrated report.
\end{abstract}

Data: A questionnaire was prepared and sent via e-mail to accounting professionals.

Tools: An analysis of the responses (both, structured and unstructured) received via Google Forms was performed.

Findings: Romanian accounting professionals are not very participative at this type of studies and have a small, general and framework-related knowledge on integrated reporting. Romanian companies are neither prepared, nor in need to adopt integrated reporting.

Contribution: This study offers an East-European perspective on integrated reporting and it relies on the persons traditionally responsible for the company's annual reporting; both aspects were never approached before in the literature.

Keywords: Integrated Reporting, integrated report, chartered accountants, financial auditors, questionnaire

JEL codes: M14, Q56

\footnotetext{
${ }^{1}$ Correspondence address: Ioana Neacşu, Romania, Email: ioana.sofian@yahoo.com.
} 


\section{Introduction}

As a developing practice in a continuous process of understanding, integrated reporting (IR) is, beyond a concept and an associated report, a product of the interaction of humans, their culture and their education. The subjective human being becomes an active participant in this phenomenon and an important influence in its development as it was conceptualized. Thus, human resources are involved in the implementation of IR and in all the associated changes within the entity, in preparing the integrated report (IRep) and also in the decisions-taking process (as an investor, analyst, employee etc.) based on the information communicated in the report.

Stakeholders agree that the academia and the bodies of accounting professionals can be a part in the development of IR through the educational process and by providing consultance in the field; at the same time, there are very few educational programs that are focused on this relatively new practice (Perego et al., 2016; Adhariani \& De Villiers, 2019).

Accounting professionals are perceived as important when it comes to the evolution of non-financial reporting (IR included). This profession is also essential for the future development of social and environmental accounting in terms of practice and professional responsibility (Kuasirikun, 2005).

In two reports made on the Sustainable Development Goals (SDG) and the Environmental, Social and Governance (ESG) information, the Association of Chartered Certified Accountants (ACCA) and the International Federation of Accountants (IFAC) explain why accountants should be on the front line in the approach of non-financial reporting and how can they contribute to its development (IFAC, 2012; ACCA, 2017): due to their discipline and rigor, professional accountants are the best placed to use a tool like IR framework in order to provide a better risk assessment and to connect social, environmental and financial value creation and destruction; investors expect reliable and high-quality information both, financial and non-financial - from accountants and not from anyone else; regardless of the digitalization of the profession, a combination with the core professional competencies of ethics, judgement, reporting and audit will still be needed; the accounting profession can assume a leadership role to connect finance with the private sector and the government.

This importance comes also from accountants' access to numbers, measurements of the impact that a company has on the environment or in society: when something occurs in the area or corporate social responsibility (CSR), the bill goes to the financial department; hence, these profesionals have the data needed for this type of reporting (Egan \& Tweedie, 2018). At the same time, new regulations 
regarding non-financial reporting, an increased market demand and an increased social attention for sustainable development pressure the professional accountants to become more engaged in providing and auditing sustainability information (Kwakyie et al., 2018).

Companies perceive non-financial reporting as a "cost thing" and are convinced that it should be approached as traditional reporting, accountants being the right professionals to do that because of their work with numbers (Egan \& Tweedie, 2018). Along with its knowledge on financial information, the accounting industry is also characterized by an advisory role to decision makers; this role supports its strategic involvement in implementing sustainability accounting and reporting in the entity (Kwakyie et al., 2018). Furthermore, accountants play a role of political mediator "by regulating the socially responsible practices of organizations [...] and by sidelining the moral dimension of human values such as altruism and benevolence as a justification for socially responsible action" (Malsch, 2013: 165).

Nevertheless, in practice, accounting profesionals lack of commitment to understand sustainability, do not have a vision of reality and tend to use the same methods in their work - both, bookkeeping and/or auditing (Egan \& Tweedie, 2018; Maas et al., 2016). Hence, although they are a key character in the evolution of non-financial reporting, professional accountants must coordinate and collaborate with their non-financial colleagues, get involved in a wider understanding of the business environment and be willing to be trained in sustainability related issues (IFAC, 2012; ACCA, 2017; Egan \& Tweedie, 2018).

Moreover, previous studies emphasize the need for research in countries where IR is in its infancy and/or voluntary in order to find if those practitioners have the same sceptic perception on IR as the ones from countries where this practice is older (Chaidali \& Jones, 2017; Feng et al., 2017).

On the base on the above, a research question is formulated as follows:

Are Romanian accounting professionals able to face the challenges of IR?

To this aim, this paper analyses the perspectives of Romanian accounting professionals on IR and on the IRep. Specifically, it relates to the following issues:

- Definition, knowledge and benefits of the concept of IR;

- The need and potential for adopting IR by Romanian companies;

- The characteristics and usefulness of the IRep.

Starting from the call of Chaidali and Jones (2017), this study focuses on Romania, a European Union (EU) member that does not have a developed practice of IR. Instead, based on its membership to the EU (from 2007), Romania translated in its legislation the EU Directive 2014/95 which requires large public-interest 
companies to publish a non-financial statement that contains component elements of an IRep. Unlike similar studies made in the Western Europe (ACCA, 2013; Van Bommel, 2014; Perego et al., 2016; Chaidali \& Jones, 2017; Lai et al., 2018; Slack \& Tsalavoutas, 2018), Romania shows an Eastern European perspective, as it is a developing country with communist history that provides an interesting setting to test a concept and/or a practice built on Western European principles. This country is also an emerging economy where are more likely to arise future businesses that are more socially and environmentally aware (ACCA, 2017).

The present study considers the opinions of Romanian accounting professionals; this includes chartered accountants and financial auditors which perform in the Romanian territory. Most of the papers that analyze humans' perception on IR are focused on investors, on managers of companies that have implemented IR or on the professionals that prepare the IRep. However, it is less known the perspective of the persons traditionally responsible for a company's annual report (financial and/or non-financial) regarding their involvement and ability to encounter the developments in the field of corporate reporting.

In the area of IR, the importance of addressing human resources separately comes from at least three reasons. First, they represent direct sources of information as regards this practice, its challenges and its benefits. Second, this human perspective it is often different from the results obtained by studying the IRep because its content is subjectively interpreted twice: when preparing the document and when analyzing its content (the most commonly used method to study reports is the content analysis - Dumitru \& Sofian, 2017). Third, studying the link between company's indicators and capital market's indicators makes it quite difficult to understand the phenomenon as a whole because this usually cannot take into account all the influencing factors (many factors are difficult to quantify). Hence, the opinion of the professionals beyond this phenomenon brings a new perspective about what IR means, how it is understood and how it is applied in practice.

This paper is structured as follows: the next part contains the literature review on other studies conducted on the human's perspective regarding IR. Section three describes the sample and the research method. Section four presents the results of the study. The last part includes conclusions and limitations of this study, as well as possible directions for future research.

\section{Stakeholders' perspective on IR}

When it comes to humans involved in the area of IR, there are two categories of papers related to this aspect: papers that study the perspective of the persons involved in designing and publishing the IRep - the preparers (Stubbs \& Higgins, 2014; Van Bommel, 2014; Chaidali \& Jones, 2017; Maroun, 2017; McNally, 
Cerbone \& Maroun, 2017; Lai et al., 2018; McNally \& Maroun, 2018; Adhariani \& De Villiers, 2019) and papers that study the different stakeholders' perspective the users (ACCA, 2013; Higgins et al., 2014; Steyn, 2014; Van Bommel, 2014; Atkins \& Maroun, 2015; Burke \& Clark, 2016; Perego et al., 2016; Stubbs et al., 2016; Slack \& Tsalavoutas, 2018; Stubbs \& Higgins, 2018; Adhariani \& De Villiers, 2019).

Not surprisingly, most of this type of studies are located in South Africa (Atkins \& Maroun, 2015; McNally et al., 2017; McNally \& Maroun, 2018; Steyn, 2014; Maroun, 2017) because in this country IR is mandatory and, thus, allows comparisons; companies in this state that experience IR operate according to the same reference framework, and the users of information are familiar with some comparable structures of ideas. Australia represents another area approached in the papers on stakeholders' perspective, based mainly on interviews: Higgins et al., 2014; Stubbs \& Higgins, 2014; Stubbs \& Higgins, 2018; Stubbs et al., 2016. The vision of the IRep preparers and of the users of the information in this document has also been explored in Europe: Italy (Lai et al., 2018), United Kingdom (ACCA, 2013; Slack \& Tsalavoutas, 2018; Chaidali \& Jones, 2017), Holland (Van Bommel, 2014). There are also studies which focus on other countries, continents or regions, individually or mixed: Perego et al., 2016; Burke \& Clark, 2016; Adhariani \& De Villiers, 2019.

\subsection{What does IR mean across the world?}

The interviews highlighted a complex nature of IR that results from the combination of four parts with the same meaning in the total: a market related part, an industry related part, a green part and a civic part (Van Bommel, 2014). In general, professionals have difficulties to provide a definition of IR; for instance, only three capital market actors and a reduced percentage of the Indonezian stakeholders declaired to be familiarized with this practice (Slack \& Tsalavoutas, 2018; Adhariani \& De Villiers, 2019). At the same time, most of the managers were unable to formulate a definition for IR and rather preffered to explain what this type of reporting it is not (Higgins et al., 2014). Their vision on IR was compared with a „strategic story-telling” (Higgins et al., 2014: 1103) and with the idea of ,meeting expectation(s)" (Higgins et al., 2014: 1105), both sintagms being also correlated with three dimensions: time, responsibility and sustainability strategy and continuous communication with stakeholders. Also, investors focused on associating IR with concepts like: risks and opportunities, link between ESG issues and financial performance, mechanism of increasing stakeholders' accountability, role of the context and professional judgement etc. (Atkins \& Maroun, 2015). 
Although some studies associate IR with impression management (Stacchezzini et al., 2016; McNally \& Maroun, 2018; Ahmed Haji \& Hossain, 2016; Melloni et al., 2017; Du Toit, 2017), the persons responsible with the preparation of the IRep do not support directly this association, but do acknowledge that entities are prudent about what they publish; more exactly, companies tend to present themselves as defenders of the environment and society, but, at the same time, they take care to maintain a profitable image in the eyes of their investors (McNally et al., 2017). Beyond this issue, the IR implementation process takes time and needs familiarization with the experience of the companies that already are on this path (Perego et al., 2016); hence, a definition would be difficult to elaborate when an entity begins this journey.

In fact, $90 \%$ of the surveyed investors support the IR model, considering that it will improve the understanding of the company's long-term strategy and it will better explain the link between sustainability and long-term performance (ACCA, 2013). However, they also consider that the IR does not provide useful information for taking decisions and they acknowledge to get all the information they need from the annual report (Slack \& Tsalavoutas, 2018).

The entrepreneurs associate IR with a rather incoherent, fragmented and contested field that still progresses despite the low level of understanding in practice of the business environment (Perego et al., 2016). Thus, this type of reporting seems to be directed more towards commercial aspects than focused on improving the current reporting model, being still unclear who its beneficiaries are (Chaidali \& Jones, 2017). Consultants in the preparation of the IRep perceive this phenomenon as a possibility for brand renewal and as a way to hide various negative aspects related to the company's performance (Chaidali \& Jones, 2017).

Nothwithstanding all these, it seems that the understanding and the development of IR are strongly influenced by the involvement of many professional accountants and investors in this process (Van Bommel, 2014). The achievement of the purpose proposed for this practice it is slowed down by its complex nature, its unclear objective, the lack of measurements for the value created, as well as by the inexistence of standards for the content and the audit of an IRep (ACCA, 2013; Slack \& Tsalavoutas, 2018).

The difficulty of comparing companies and the lack of coherence in reporting are accentuated by the voluntary nature of this practice (Slack \& Tsalavoutas, 2018), which is why a third of a study's respondents argued for a combination of voluntary and mandatory, especially as regards the significance of the content elements and the assurance of the IRep (Stubbs \& Higgins, 2018). Hence, although in some coutries, a mandatory approach is successful (Indonesia - Adhariani \& De Villiers, 2019), it is still too soon for this practice to become mandatory, even if its voluntary feature does not necessarily lead to a superior quality of the information 
provided, but it encourages companies to learn from those that have already implemented IR (Stubbs \& Higgins, 2018).

As regards the IR assurance, some stakeholders believe that the auditing process should be similar to the one for financial statements (Adhariani \& De Villiers, 2019), but the professional auditors consider that the traditional methods are not adequate because the format of IR includes a forward-looking approach based on qualitative and quantitative information (Maroun, 2017). The assurance of an IRep represents both, a need and a challenge (McNally et al., 2017; Stubbs \& Higgins, 2018; Adhariani \& De Villiers, 2019), but it would also reduce the relevance of the information presented by removing from its content certain management comments or projects (Atkins \& Maroun, 2015).

Stakeholders do not perceive the same benefits for IR as compared to the studies that analyze companies' reports or their status on the capital market. For instance, department managers, Generali's IRep preparers and some Indonezian stakeholders consider benefits of IR the following: an improved reputation and therefore easier obtainance of financial resources for the company (Steyn, 2014), a better understanding of the value created (Burke \& Clark, 2016), an improved communication within the entity and developments in some areas of the company (Burke \& Clark, 2016; Lai et al., 2018), a better relationship with the stakeholders (Steyn, 2014; Burke \& Clark, 2016; Adhariani \& De Villiers, 2019) etc. On the other hand, cost reduction and a better allocation of resources were not identified as benefits for IR; on the contrary, stakeholders point out that preparing an IRep involves substantial costs (Steyn, 2014). Also, the managers and the preparers consider that it is difficult to identify a benefit for this phenomenon both, for the company or the stakeholders (Chaidali \& Jones, 2017).

\subsection{What are the characteristics and the usefulness of an IRep?}

The IIRF was perceived by most participants in a symposium in the field of IR as a good guide for the preparation of an IRep, even if the notions of its quality and assurance are still in development (Burke \& Clark, 2016). Although the International Integrated Reporting Council (IIRC)'s concept implies the same involvement in writing the IRep from the beginning until its end, the preparers know that stakeholders do not read the entire document, but focus on the section related to their area of interest (Stubbs et al., 2016; Chaidali \& Jones, 2017).

Management is often taking the decision to prepare an IRep without a prior study of this decision's impact on internal mechanisms (McNally et al., 2017). At the same time, most of the managers believe that the IRep it is nothing more than the current annual report with a few undefined and unclear elements that make it more complicated (Chaidali \& Jones, 2017). Investors believe that the persons preparing 
the IRep perceive the IIRF's instructions as a list of steps to be checked, based on their experience with financial statements (Atkins \& Maroun, 2015), aspect that reduces the possibility of achieving integrated thinking within the company (McNally et al., 2017). Indeed, at internal level, there are difficulties in the interaction of the groups responsible for preparing the IRep (usually the financial and the sustainability team), especially regarding the roles played by each party; the preparers do not have enough time for reflection and argue that the nonfinancial information included in this document is not relevant because investors base their decision mainly on financial statements (McNally et al., 2017). Other obstacles to the preparation of an IRep are the lack of adequate systems for producing the information that can be included in this document or the fear of disclosing high-sensitivity information (Adhariani \& De Villiers, 2019). In addition, investors perceive the big audit firms as responsible for a „mechanized" (Atkins \& Maroun, 2015: 212) process of preparing an IRep in their own financial interest.

Hence, attempting to meet as many informational needs as possible through the presentation of all the resources used in the business cycle, as well as the uncertainty about what needs to be reported, determine the entities to be inspired from codes of good practice or from competitors' practice and, thus to publish voluminous and repetitive reports (Atkins \& Maroun, 2015; Chaidali \& Jones, 2017; McNally et al., 2017).

In order to determine the materiality of the elements considered for inclusion in the IRep, the preparers base this process on the use of the GRI standards (Stubbs \& Higgins, 2014) and, at the same time, consider that incorporating elements that quantify ESG aspects improves its quality (McNally et al., 2017). In the same vein, the first part of a report drawing attention is the general manager's or the CEO's message, followed by the governance issues and by the section describing the company's performance (Stubbs et al., 2016). Managers believe that an IRep should focus more on the business model than on social and environmental issues (Chaidali \& Jones, 2017). Preparers consider that obtaining a good IRep implies reflecting the business model and the strategy as key elements of the value creation process, while sustainability issues are marginalized because this document was not built in this regard, nor is the entity ready to include sustainability challenges in its value creation story (Lai et al., 2018).

Consequently, a lack of understanding of the role and logic of IR makes it difficult to involve those responsible with IRep preparation who, regardless of their qualification and experience, need time to change their perception about corporate reporting, to be able to understand and explain the behavior of the entity and the value created (Stubbs \& Higgins, 2014; McNally \& Maroun, 2018). In addition, the purpose that information producers attribute to an IRep shows that they perceive this document as a process of external communication, not as a process of 
improving internal management or building integrated thinking within the company (Perego et al., 2016). For example, the experts who compile Generali's IRep tend to maintain a constant dialogue with potential readers in order to continuously improve the understanding and usefulness of this report (Lai et al., 2018).

However, there is a strong belief that preparing an IRep involves high costs and considerable time-consuming resources (Chaidali \& Jones, 2017; McNally et al., 2017; Adhariani \& De Villiers, 2019). Moreover and surprisingly, although most of the interviewed stakeholders agreed that the target group of the information in such report is represented by the actual and potential investors (Lai et al., 2018; Adhariani \& De Villiers, 2019), the investors' community does not perceive itself as the main beneficiary (Stubbs et al., 2016).

Although the main objective of the IIRC is still far from being achieved, investors generally have a positive attitude towards the usefulness of the IRep, considering that it gives them more support in decision-taking and that it is a way to improve companies' credibility on financial markets (Atkins \& Maroun, 2015). However, they consider that the current reporting practices are characterized by too much congestion (managers show too much discretion in figures' reporting), a lack of transparency and clarity (ACCA, 2013) and present impression management techniques that affect the quality of the information communicated (Atkins \& Maroun, 2015). In addition, investors use the IRep as a measure to verify information from other sources and also before relating directly to the company because direct communication with the entity remains the most viable source of information (Stubbs et al., 2016).

Doubts about the usefulness of the IRep also exist among its preparers both, at the operational level or in relation to the stakeholders (McNally et al., 2017). Thus, one of the main challenges encountered in preparing the IRep is to identify the optimal way to integrate key elements in the communication of value creation in order to reduce the complexity of the document and increase its attractiveness; moreover, the IRep is an appropriate tool for these purposes, even if its preparers make efforts to translate the accounting data into text and to use a visually appealing format in this regard (Lai et al., 2018).

\section{Research method}

\subsection{Context - Romania}

Romania represents an interesting setting as regards the objective of this study for three reasons. First, it is an EU member state from Eastern Europe. Second, it is a developing country, thus a potential space for the implementation of IR. Third, it 
has a communist history that provides a difference of perspectives when it comes to understanding a practice developed in Western Europe by active economists who had completed their professional education in Eastern Europe, during the communist period or in the period following the transition to democracy.

At present, Romanian companies do not practice IR; the IIRC database with examples of integrated reports does not include any Romanian company and 42 Romanian entities publish reports according to the Global Reporting Initiative standards (Sustainability Disclosure Database, 2021). In fact, any type of nonfinancial reporting is voluntary in the Romanian territory, with the exception of the entities with over 500 employees. It is the case of the entities covered by the transposition of the EU Directive 2014/95 in the Romanian regulations - Order of the Ministry of Finance no. 1938/2016 and Order of the Ministry of Finance no. $3456 / 2018$ - for which publishing a non-financial statement is mandatory. A website was also developed in order to keep updated all the entities that have or want to publish a non-financial report (https://declaratie-nefinanciara.ro/).

As regards the institutions dedicated to sustainability, in the fall of 2017, there was founded the Sustainability Ambassy in Romania through a partnership between The CSR Agency and a Romanian hypermarket chain (Kaufland Romania). This non-profit organization promotes the sustainability and the development of specific competencies, programs and partnerships between businesses, civil society and the public sector in Romania, in order to align with the 2030 Agenda and achieve the objectives of sustainable development (Ambasada Sustenabilitatii, 2021).

Nevertheless, Romanian academia addresses the subject of IR in international and/or national journal papers, which shows that, at least at a theoretical level, this phenomenon it is known among the accounting proffessors. This subject was approached from the analysis of the comment letters received by the IIRC for the Consultation Draft of the IIRF (Oprișor, 2015; Dumitru \& Gușe, 2017) until the integrated reports' assurance (Dumitru \& Gușe, 2016). A general presentation of the IIRC, the IR's guiding principles (Lapteș \& Sofian, 2016), the communication of social and environmental information (Turturea, 2015) and the value creation concept and communication process (Dumitru et al., 2015; Sofian, 2017) was also made. Two extensive literature reviews (Dumitru \& Sofian, 2017; Caraiani et al., 2018) confirmed an evolution, an extending analysis of IR practice, a focus on econometrics or content analysis as research methods and a need for more IR impact studies. There seems to be no single theory to explain IR, as a combination of several theories balances their explanatory power by incorporating the perspectives of information producers and users (Dragu \& Tiron-Tudor, 2014). Romanian academia found that voluntary adoption of IR is influenced by both, political and economical factors (Dragu \& Tiron-Tudor, 2013; Tiron-Tudor \& Dragu, 2014) and that publishing an IRep could have a positive influence on firm value measured through Tobin's Q (Sofian, 2019). IR practices were also analyzed, 
collectively (Chersan, 2015), or individually through case studies: Takeda (Dumitru \& Jinga, 2015), Danone (Lapteș \& Sofian, 2017). Research was performed on the adoption of IR principles (Sofian, 2016; Avram et al., 2018) or the compliance with the IIRF (Sofian \& Dumitru, 2017) of companies' integrated reports operating in different sectors of activity. However, although many papers written by Romanian authors debate the subject of IR, only one of them (Sofian, 2016) has the research based in the Romanian space and on Romanian companies.

This is why this study focuses on Romania and on Romanian accounting professionals. There is a gap in the literature on both aspects: space and subjects.

\subsection{Sample}

In order to achieve the objective proposed, it was selected a sample of chartered accountants and financial auditors that are either independent or part of a company. These persons are Romanian and their e-mail addresses were sourced from public registers available on the websites of the reprezentative organizations: The Body of Expert and Licensed Accountants of Romania (ro., Corpului Experților Contabili și Contabililor Autorizați din România - CECCAR); The Chamber of Financial Auditors of Romania (ro., Camera Auditorilor Financiari din România - CAFR). The search in the public registers provided 312 valid e-mail addresses.

Based on the fact that, in Romania, the professionals in the financial field are often members of both, CECCAR and CAFR, these two groups can be taken into account together for this study, because they are usually formed by the same persons. Thus, this study aims to know the perspectives on IR of the traditional practitioners, especially of the persons that will be involved in preparing the IRep.

\subsection{Questionnaire}

As seen in the second part of this paper, most of the studies on stakeholders' perspective use the interview as method for the research. Nevertheless, this study uses a questionnaire developed on the conclusions of the previous papers. From a methodological point of view, prior to the preparation and distribution of such tool, a test it is recommended on a smaller sample that can use interviews, with the purpose to evaluate the questionnaire's structure in order to further obtain better results on the researched sample (Capotă et al., 2006).

The questionnaire contains 20 questions written in Romanian, it was built on previous results in the field and designed using the Google Forms tool (https://www.google.com/forms/about/). It contains both, open questions and closed questions, with single or multiple choice answers. In order to provide a 
better understanding of the results, the answers were translated and adapted to English. A brief presentation of the questionnaire can be found in Appendix A.

The first question aims to separate the persons who are familiar (even to a small extent) with the concept of IR and the persons that are not. If the respondent chooses the last option (not familiar with IR), then it is invited to provide some general personal information. If the respondent shows a minimum knowledge of IR, it will continue to debate on the main subject through his or hers answers to the following questions. In order to facilitate the analysis, the options of answer regarding the level of knowledge of IR were codified into a sort of Likert scale as it can be seen in Appendix B. 13 questions are dedicated for the main objective of this study and six questions aim to characterize the sample: respondents' age, studies, his or hers position in the entity where he or she activates, his or hers work experience (years) and the entity's sector of activity.

There are seven questions dedicated to the concept of IR and its potential to be implemented in Romania. The second question aims to find a definition for IR; an open question was chosen because a closed one would have limitated the answer to words or phrases inspired from the official version. Questions number two and 11 target the identification of key concepts that Romanian accountants and auditors associate to IR. Moreover, based on the study of Stubbs and Higgins (2018), the questionnaire explores the potential mandatory characteristic of IR (question number 14). Questions three, four, nine and ten aim to understand if there is a need for IR in Romania and if the respondents' belonging entities would benefit from it or would have enough resources to implement it. The question regarding the expected benefits is closed, with four possible answers formulated on the base of previous conclusions on this subject (Eccles \& Saltzman, 2011; Steyn, 2014; Burke \& Clark, 2016; Lai et al., 2018; Adhariani \& De Villiers, 2019). This last question was also codified in order to facilitate the analysis (see Appendix B).

As regards the concept of IRep, six questions are dedicated to its characteristics and utility. For instance, the question number five establishes how useful and well known is the IIRF in the process of preparing an IRep. The answer options are based on both, the opinions about the IIRF (Kuzina, 2014; Morros, 2016) and the existence of the IIRC database with examples of reports that are models of approaching a certain guiding principle or content element. The options of answer of this question were also codified into a sort of Likert scale in order to provide a better view of the data resulted from the questionnaire (see Appendix B). In addition, based on the different opinions concerning the utility of an IRep, there were also approached the following subjects: the target group of users of the information in an IRep (question number six), the main content element of this document (question number 13), its optimum length (question number 12) and its preparers (questions number seven and eight). 
The questionnaire was sent via e-mail in April 2018, but there were recieved only 12 answers in a period of three months. For this reason, the questionnaire was sent again in July 2018 to the same persons and this last act contributed to the obtainance of a total number of 18 answers from the Romanian chartered accountants and financial auditors. Although the response rate is low (5.77\%) and, implicitly, unrepresentative to generalize the results, the obtained perspectives allow outlining an interesting vision on the phenomenon of IR in Romania.

\section{Research results}

\subsection{Respondents' characteristics}

Among the professional accountants that have answered to the questionnaire, half of the respondents are over 55 years old and $33.33 \%$ have the age between 36 and 45 years old. $56 \%$ of the respondents have a master degree and $39 \%$ have a bachelor degree in an economic area. Moreover, $83 \%$ of the respondents are employees of an entity that provides services, $67 \%$ are general managers and all the respondents have over 10 years of work experience. Taken into account that most of the respondents occupy a manager position (either general or in a department) in the entity they belong to and only a third of them are actual employees, these characteristics were not considered very usefull to provide some interesting inputs for the analysis. Thus, for the following results, there were performed some crosssectional analyses based on the respondents' age, education and field of work. In addition, in order to avoid repetition, for accounting professionals there were also used terms like accountants, professionals, experts.

\subsection{The IR concept and its developing potential in Romania}

Romanian accountants and financial auditors have, in general, a reduced level of knowledge of the IR concept (an average score of 1.35 out of a maximum score of 3). As it can be seen in Appendix B, a high level of knowledge is associated with the access to an IRep (either for preparing it or just consulting it); a medium level of knowledge involves knowing the literature about IR from national and/or international journals; and a low level of knowledge means only a familiarity with this practice, without knowing very well its characteristics. At the same time, the first question was a multiple choice one. Hence, when it comes to the total of responses for this question, it should be taken into account that one person could have checked more than one option of answer.

As it can be observed in Table 1, for $22 \%$ of the respondents this concept is completely unknown. All of them have an economic bachelor degree and work in services area. Although for half of them it is understandable not knowing about IR (they are over 55 years old), for the other half is not, especially as regards the 
person that is between 36 and 45 years old who, ten years ago (when the IIRC was born), would have just graduated a faculty in the field. However, in Romania this practice is not developed at all.

On the other hand, $71 \%$ of the professionals who have heard about IR, but do not know very much about its characteristics are over 55 years old. The $39 \%$ of the respondents with a low level of IR knowledge have an economic degree (similar proportions for bachelor and master) and one person works in production. The same percentage of respondents (39\%) admit to be familiar with the IR literature; among them, there is one accountant with an economic $\mathrm{PhD}$ and the rest is graduated of a master degree (all, except one, in an economic profile). These experts can be found acros different types of activity: either in a production entity or part of a public institution or, most of them, in a firm that provides services.

In addition, only two professionals (11\%) state that had access to and consulted an IRep. These are also familiar with the IR literature and accumulate a proportion of $11 \%$ of the sample with a high level of IR knowledge. An interesting fact is that, among them, there is one person who is over 55 years old.

Table 1. Romanian accountants and financial auditors' level of knowledge of the IR concept

\begin{tabular}{|c|c|c|c|c|c|c|}
\hline \multicolumn{3}{|c|}{$\begin{array}{l}\text { Level of knowledge } \\
\text { No. of respondents } \\
\text { (percentage) }\end{array}$} & $\begin{array}{c}\text { None - 0 } \\
4 \\
(22 \%) \\
\end{array}$ & $\begin{array}{c}\text { Low - } 1 \\
7 \\
(39 \%) \\
\end{array}$ & $\begin{array}{c}\text { Medium - 2 } \\
7 \\
(39 \%) \\
\end{array}$ & $\begin{array}{c}\text { High - 3 } \\
2 \\
(11 \%) \\
\end{array}$ \\
\hline \multirow{12}{*}{ 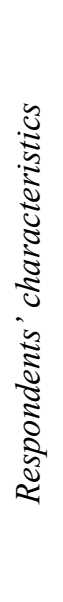 } & & $26-35$ & $0 \%$ & $14.29 \%$ & $0 \%$ & $0 \%$ \\
\hline & $\therefore \bar{a}$ & $36-45$ & $25 \%$ & $14.29 \%$ & $57.14 \%$ & $50 \%$ \\
\hline & $\nabla \cong$ & $46-55$ & $25 \%$ & $0 \%$ & $14.29 \%$ & $0 \%$ \\
\hline & & $>55$ & $50 \%$ & $71.42 \%$ & $28.57 \%$ & $50 \%$ \\
\hline & & Bachelor & $100 \%$ & $42.86 \%$ & $0 \%$ & $0 \%$ \\
\hline & $\Xi$ & Master & $0 \%$ & $57.14 \%$ & $85.71 \%$ & $100 \%$ \\
\hline & క్ర & $P h D$ & $0 \%$ & $0 \%$ & $14.29 \%$ & $0 \%$ \\
\hline & iิ & Economic & $100 \%$ & $100 \%$ & $85.71 \%$ & $50 \%$ \\
\hline & & Non-economic & $0 \%$ & $0 \%$ & $14.29 \%$ & $50 \%$ \\
\hline & $\underset{\pi}{\pi}$ & $\begin{array}{l}\text { Production, } \\
\text { industry }\end{array}$ & $0 \%$ & $14.29 \%$ & $14.29 \%$ & $0 \%$ \\
\hline & క & Services & $100 \%$ & $85.71 \%$ & $71.42 \%$ & $100 \%$ \\
\hline & 3 & Public institution & $0 \%$ & $0 \%$ & $14.29 \%$ & $0 \%$ \\
\hline \multicolumn{3}{|c|}{ Mean } & \multicolumn{4}{|c|}{1.35} \\
\hline \multicolumn{3}{|c|}{ Median } & \multicolumn{4}{|c|}{1} \\
\hline \multicolumn{3}{|c|}{ Standard deviation } & \multicolumn{4}{|c|}{0.9333} \\
\hline
\end{tabular}

Vol. 20, No. 1 
From this point forward, every other analysis will also take into account (where relevant) the level of IR knowledge.

As regards the definition of IR, only the respondents considered to have a high level of IR knowledge provide closer definitions to the one promoted by the IIRC. Although both professional accountants work in services and have a master degree, in their definitions there can be observed a difference of approach based on age and field of education: while the youngest respondent with an economic degree delivers a more integrated and modern view, using key terms for IR (IR allows "stakeholders' information about the strategy, the performance and the governance of an entity, as well as about the manner in which all of these create value" translation and adaptation from respondent number seven), the older respondent graduated of another profile offers a more structured definition, with traditional accounting language (IR represents "a system of practices and procedures that lead to designing a report that provides, in a more complex way, the current picture, comparisons with previous pictures and the future picture of a company seen from a global perspective, and that presents more accurately the non-financial information" - translation and adaptation from respondent number nine).

The key concepts found in the definitions provided by the respondents with a medium or a low level of IR knowledge are the following: one report (respondent number 11), obtained through combining other types of reports (respondent number one), which includes both, financial and non-financial information (respondent number 11), with the purpose to present the objectives and the business strategy (respondents five and 11), in order to support better decisions and a more efficient allocation of resources (respondents four and five). Moreover, there are also used phrases like: "transparent reporting" (respondent number 11) and "360 degrees reporting" (respondent number eight).

When it comes to associate a concept to IR, regardless of the level of knowledge (low, medium or high), most of the respondents perceive IR to be similar to annual (financial) reporting. Hence, as it can be observed in Table 2, 79\% of the respondents (11 persons) who are at some extent familiar with IR consider that this practice can be associated to a 'fair image' concept. This may be because nine persons ( $81.82 \%$ of them) have a low or a medium level of IR knowledge.

As this question was also with multiple choice, it is interesting to outline that respondent number two (over 55 years old, with an economic master degree and working in services) added the 'creative accounting' and the respondent number 11 (between 46 and 55 years old, with an economic master degree and operating in a production entity) added the 'impression management' to the 'fair image' concept. Thus, there are some opinions that see a connection between impression management (14\%) or creative accounting (7\%) and IR. 
In addition, a professional accountant with a low level of IR knowledge considers that the information provided in an IRep is of questionable quality - a surprising opinion, taken into account that it is the youngest respondent and it would be expected to be more open to new types of reporting; at the same time, it is also true that the IRep's assurance is still under development. Furthermore, the respondent with an economic $\mathrm{PhD}$ did not provide an answer to this question.

Table 2. The concept associated to IR by the Romanian accounting profesionals

\begin{tabular}{|c|c|c|c|c|c|c|}
\hline \multicolumn{3}{|c|}{ Concept } & $\begin{array}{l}\text { Fair } \\
\text { image }\end{array}$ & $\begin{array}{l}\text { Creative } \\
\text { acc. }\end{array}$ & $\begin{array}{l}\text { Impression } \\
\text { manag. }\end{array}$ & $\begin{array}{l}\text { Questionable } \\
\text { info quality }\end{array}$ \\
\hline \multicolumn{3}{|c|}{$\begin{array}{l}\text { No. of respondents } \\
\text { (percentage) }\end{array}$} & $\begin{array}{c}11 \\
(79 \%) \\
\end{array}$ & $\begin{array}{c}1 \\
(7 \%) \\
\end{array}$ & $\begin{array}{c}2 \\
(14 \%) \\
\end{array}$ & $\begin{array}{c}1 \\
(7 \%)\end{array}$ \\
\hline \multirow{6}{*}{ 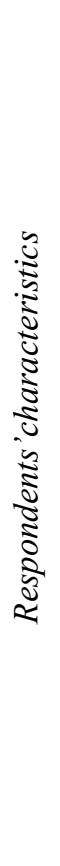 } & 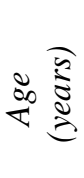 & $\begin{array}{l}26-35 \\
36-45 \\
46-55 \\
>55\end{array}$ & $\begin{array}{r}0 \% \\
36.36 \% \\
9.09 \% \\
54.55 \%\end{array}$ & $\begin{array}{r}0 \% \\
0 \% \\
0 \% \\
100 \%\end{array}$ & $\begin{array}{r}0 \% \\
0 \% \\
50 \% \\
50 \%\end{array}$ & $\begin{array}{r}100 \% \\
0 \% \\
0 \% \\
0 \%\end{array}$ \\
\hline &.$\tilde{\Omega}$ & $\begin{array}{l}\text { Bachelor } \\
\text { Master } \\
\text { PhD }\end{array}$ & $\begin{array}{r}18.18 \% \\
81.82 \% \\
0 \%\end{array}$ & $\begin{array}{r}0 \% \\
100 \% \\
0 \%\end{array}$ & $\begin{array}{r}50 \% \\
50 \% \\
0 \%\end{array}$ & $\begin{array}{r}0 \% \\
100 \% \\
0 \%\end{array}$ \\
\hline & $\underset{\mathbb{J}}{\stackrel{\Xi}{\Xi}}$ & $\begin{array}{l}\text { Economic } \\
\text { Non- } \\
\text { economic }\end{array}$ & $\begin{array}{r}90.91 \% \\
9.09 \%\end{array}$ & $\begin{array}{r}100 \% \\
0 \%\end{array}$ & $\begin{array}{r}100 \% \\
0 \%\end{array}$ & $\begin{array}{r}100 \% \\
0 \%\end{array}$ \\
\hline & $\frac{\pi}{2}$ & $\begin{array}{l}\text { Production, } \\
\text { industry }\end{array}$ & $18.18 \%$ & $0 \%$ & $50 \%$ & $0 \%$ \\
\hline & $\frac{\sqrt[3]{5}}{\frac{1}{0}}$ & $\begin{array}{l}\text { Services } \\
\text { Public } \\
\text { institution }\end{array}$ & $\begin{array}{r}81.82 \% \\
0 \%\end{array}$ & $\begin{array}{r}100 \% \\
0 \%\end{array}$ & $\begin{array}{r}50 \% \\
0 \%\end{array}$ & $\begin{array}{r}100 \% \\
0 \%\end{array}$ \\
\hline & 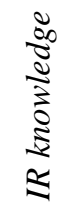 & $\begin{array}{l}\text { Low } \\
\text { Medium } \\
\text { High }\end{array}$ & $\begin{array}{l}45.45 \% \\
36.37 \% \\
18.18 \%\end{array}$ & $\begin{array}{r}0 \% \\
100 \% \\
0 \%\end{array}$ & $\begin{array}{r}50 \% \\
50 \% \\
0 \%\end{array}$ & $\begin{array}{r}100 \% \\
0 \% \\
0 \%\end{array}$ \\
\hline
\end{tabular}

Regardless the level of knowledge, $92.86 \%$ of the respondents consider that the IRep is necessary, despite of the existence of the sustainability report and/or the CSR report. As motivations for this need, there are provided the following: current reporting does not contain all the information an investor needs and it is based on historical data (respondent number five), the IRep congregates all the information into one document, improving the access to it and increasing efficiency (respondents seven, 10 and 12) and it offers a comprehensive view over the business (respondents four, eight and 11). In addition, the complexity of the financial information seems to be the one that justifies the need for an IRep in the eyes of a professional accountant with over 55 years old (respondent number two), but with a medium level of IR knowledge. On the other hand, according to the 
youngest respondent with a low level of IR knowledge, this need does not exist because "not all users are interested in all that information" (translation and adaptation from respondent number one).

As regards the benefits of IR (Table 3), Appendix B shows that, among the options of answer, there were considered two internal benefits - a better internal communication (internal 1) and a better knowledge of the entity and of the roles of its members (internal 2) and one external benefit - a better reputation in the business environment and/or on the financial markets (external). These three options were chosen because they group the most identified benefits in the literature; the last option of answer suggested the idea that maybe IR does not bring any additional benefits than previous reporting practices. At the same time, the question regarding IR benefits was multiple choice and it was related to the entity the respondent belonged to.

Table 3. The opinion of Romanian accountants and financial auditors regarding the benefits of $I R$

\begin{tabular}{|c|c|c|c|c|c|c|}
\hline \multicolumn{3}{|c|}{ Expected benefits } & $\begin{array}{c}\text { Internal } \\
(1) *\end{array}$ & Internal $(2)^{*}$ & External* & $\begin{array}{c}\text { None } \\
\text { additional* }\end{array}$ \\
\hline \multicolumn{3}{|c|}{ No. of respondents (percentage) } & $\begin{array}{c}3 \\
(21 \%) \\
\end{array}$ & $\begin{array}{c}5 \\
(36 \%) \\
\end{array}$ & $\begin{array}{c}11 \\
(79 \%) \\
\end{array}$ & $\begin{array}{c}1 \\
(7 \%) \\
\end{array}$ \\
\hline \multirow{5}{*}{ 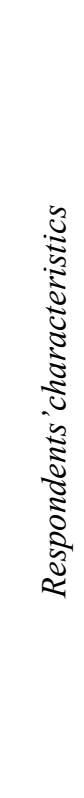 } & 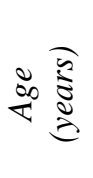 & $\begin{array}{l}26-35 \\
36-45 \\
46-55 \\
>55\end{array}$ & $\begin{array}{r}0 \% \\
66.67 \% \\
33.33 \% \\
0 \%\end{array}$ & $\begin{array}{r}0 \% \\
60 \% \\
20 \% \\
20 \%\end{array}$ & $\begin{array}{r}9.09 \% \\
36.37 \% \\
9.09 \% \\
45.45 \%\end{array}$ & $\begin{array}{r}0 \% \\
0 \% \\
0 \% \\
100 \%\end{array}$ \\
\hline & 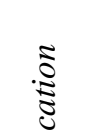 & $\begin{array}{l}\text { Bachelor } \\
\text { Master } \\
\text { PhD }\end{array}$ & $\begin{array}{r}0 \% \\
66.67 \% \\
33.33 \%\end{array}$ & $\begin{array}{l}20 \% \\
60 \% \\
20 \%\end{array}$ & $\begin{array}{r}18.18 \% \\
72.73 \% \\
9.09 \%\end{array}$ & $\begin{array}{r}0 \% \\
100 \% \\
0 \%\end{array}$ \\
\hline & 式 & $\begin{array}{l}\text { Economic } \\
\text { Non-economic }\end{array}$ & $\begin{array}{r}100 \% \\
0 \%\end{array}$ & $\begin{array}{r}100 \% \\
0 \%\end{array}$ & $\begin{array}{r}90.91 \% \\
9.09 \%\end{array}$ & $\begin{array}{r}100 \% \\
0 \%\end{array}$ \\
\hline & 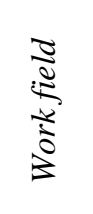 & $\begin{array}{l}\text { Production, } \\
\text { industry } \\
\text { Services } \\
\text { Public } \\
\text { institution }\end{array}$ & $\begin{array}{l}33.33 \% \\
33.34 \% \\
33.33 \%\end{array}$ & $\begin{array}{l}40 \% \\
20 \%\end{array}$ & $\begin{array}{r}81.82 \% \\
9.09 \%\end{array}$ & $\begin{array}{r}100 \% \\
0 \%\end{array}$ \\
\hline & $\leqslant \frac{\frac{\sqrt{2}}{\frac{8}{3}}}{\frac{8}{3}}$ & $\begin{array}{l}\text { Low } \\
\text { Medium } \\
\text { High }\end{array}$ & $\begin{array}{r}0 \% \\
100 \% \\
0 \%\end{array}$ & $\begin{array}{r}20 \% \\
80 \% \\
0 \%\end{array}$ & $\begin{array}{l}45.45 \% \\
36.37 \% \\
18.18 \%\end{array}$ & $\begin{array}{r}100 \% \\
0 \% \\
0 \%\end{array}$ \\
\hline
\end{tabular}

$79 \%$ of the accounting professionals that are familiar with the concept consider that IR brings first a better visibility externally, thus improving a company's image and 
reputation as identified in previous studies (Eccles \& Serafeim, 2011; Eccles \& Saltzman, 2011; Krzus, 2011; EY, 2013; Steyn, 2014; IMA, 2016; Paolucci \& Cerioni, 2017). It seems that with this benefit agree respondents of all ages - mostly over 55 years old (five persons - 46\% of them) and between 36 and 45 years old (four persons - $37 \%$ of them) - , with all types of degrees (73\% of them with a master degree, one not economic), working in all types of fields - with a majority for services provider - and regardless the level of IR knowledge (both persons with high level, five persons with low level and four persons with medium level).

At the same time, more than half of the respondents (57\%) agree that IR brings also internal benefits, such as improved communication between departments or a better knowledge of the activity of the entity and the awareness of its employees about their role in the organization. These results were also confirmed by previous researches (EY, 2013; Adams, 2014; Black Sun, 2014; Adams, 2015; Burke \& Clark, 2016; Paolucci \& Cerioni, 2017; Lai et al., 2018). The characteristics of the accountants who support internal benefits are similar, but it is to be notified that the persons considered to have a high level of IR knowledge do not acknowledge any internal benefits.

The respondents were generally reluctant with respect to the current potential of IR to be implemented in the entity they belong to. Some of the answers argue that it is not necessary because the entity is too small for it (respondent number three) and some claim that it involves too many resources (both, financial and of time) which the Romanian entities do not have (respondents one, two, four, eight, nine and 12). However, even if the entity has all of these resources, it is facing insufficient documentation (respondent number 16). By consequence, specialists that understand this concept are required and there is also a need of time to train the future preparers of the IRep (respondent number seven).

Moreover, although the respondents one and five have graduated an economic master degree and work in services, their opinion about the need and resources for IR differs because respondent number five (between 36 and 45 years old, familiar with IR at a medium level) considers that IR is maybe "the most intelligent investment in knowing the potential and the limits of a business that each entity should make" (translation and adaptation from respondent number five), while respondent number one (between 26 and 35 years old, with a low level of IR knowledge) perceives the practice of IR as an additional cost "agreed by the big ones to marginalize the little ones" (translation and adaptation from respondent number one). Two professional accountants (respondents numbers 10 and 11) believe that IR could be implemented in Romanian big companies, based on the idea that "if one wants, one can do it" (translation and adaptation from respondent number 11). One of them has a low level of IR knowledge and works in services and the other one has a medium level of IR knowledge and works in a production entity. 
When it comes to the debate of mandatory versus voluntary IR, opinions do not concur in one direction or another and few experts actually justify their point of view. Hence, the number of persons that are in favour of mandatory IR $(28.57 \%)$ is similar to the number of persons that are against this option $(21.43 \%)$. The respondents with a high level of IR knowledge claim that IR should be mandatory only for some categories of organizations, such as big companies (respondent number nine) or public interest entities (respondent number seven). Three out of four persons that are in favor of mandatory IR have a medium level of IR knowledge. All of the respondents that are in favor of voluntary IR have a low level of IR knowledge. Only the mandatory IR is motivated as an option that offers a comprehensive view of the business (respondent number 11 - works in a production entity) and supports efficiency and performance (respondent number 16 - works in services). At the same time, one professional accountant that works in a production entity and has a low level of IR knowledge considers that the decision to publish an IRep should belong to the company's management. This issue was also found previously in the practice of the companies that implemented IR (McNally \& Maroun, 2018). Other research also proved that if the decision of change comes from the top management, the accountants will not resist that much to it (Egan \& Tweedie, 2018).

\subsection{The concept of IRep: its characteristics and its utility}

Although so intensely debated in the literature, Romanian accountants and financial auditors (57\% of the respondents) also consider that the target group of the IRep is represented by the investors (and/or managers). Table 4 outlines the profile of the respondent that admits this target group: age between 36 and 45 years or over 55 years, with an economic master degree, works in an entity providing services and has a low or a medium level of IR knowledge.

The community and/or the government are perceived as the user of the information provided in an IRep in proportion of $29 \%$ of the answers. This result is in accordance with the idea that an IRep should focus less on sustainaibility issues and more on the business model (Chaidali \& Jones, 2017; Lai et al., 2018). One person with high level of IR knowledge considers the community to be the main user of IR information and the majority of these respondents are over 55 years old.

In addition, a less expected and previously unindentified user of the information provided by an IRep is represented by the financial institutions, such as banks and/or insurance firms (14\%). This option was also supported by the only person in the sample with an economic $\mathrm{PhD}$. 
Table 4. The perception of Romanian accountants and financial auditors about the IRep's users

\begin{tabular}{|c|c|c|c|c|c|}
\hline \multicolumn{3}{|c|}{ Target users } & $\begin{array}{c}\text { Managers, } \\
\text { investors }\end{array}$ & $\begin{array}{l}\text { Community, } \\
\text { government }\end{array}$ & $\begin{array}{c}\text { Financial } \\
\text { institutions }\end{array}$ \\
\hline \multicolumn{3}{|c|}{ No. of respondents (percentage) } & $\begin{array}{c}8 \\
(57 \%)\end{array}$ & $\begin{array}{c}4 \\
(29 \%)\end{array}$ & $\begin{array}{c}2 \\
(14 \%)\end{array}$ \\
\hline \multirow{5}{*}{ 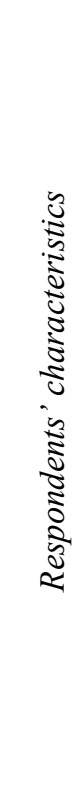 } & 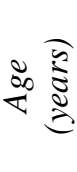 & $\begin{array}{l}26-35 \\
36-45 \\
46-55 \\
>55\end{array}$ & $\begin{array}{l}12.5 \% \\
37.5 \% \\
12.5 \% \\
37.5 \%\end{array}$ & $\begin{array}{r}0 \% \\
25 \% \\
0 \% \\
75 \%\end{array}$ & $\begin{array}{r}0 \% \\
50 \% \\
0 \% \\
50 \%\end{array}$ \\
\hline & 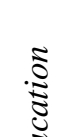 & $\begin{array}{l}\text { Bachelor } \\
\text { Master } \\
\text { PhD }\end{array}$ & $\begin{array}{r}25 \% \\
75 \% \\
0 \%\end{array}$ & $\begin{array}{r}25 \% \\
75 \% \\
0 \%\end{array}$ & $\begin{array}{r}0 \% \\
50 \% \\
50 \%\end{array}$ \\
\hline & $\underset{\mathbb{1}}{\vec{Z}}$ & $\begin{array}{l}\text { Economic } \\
\text { Non-economic }\end{array}$ & $\begin{array}{l}87.5 \% \\
12.5 \%\end{array}$ & $\begin{array}{r}100 \% \\
0 \%\end{array}$ & $\begin{array}{r}100 \% \\
0 \%\end{array}$ \\
\hline & $\begin{array}{l}\frac{3}{2} \\
\frac{\pi}{3} \\
\vdots \\
0 \\
\frac{\pi}{2}\end{array}$ & $\begin{array}{l}\text { Production, } \\
\text { industry } \\
\text { Services } \\
\text { Public } \\
\text { institution }\end{array}$ & $\begin{array}{r}25 \% \\
75 \% \\
0 \%\end{array}$ & $\begin{array}{r}100 \% \\
0 \%\end{array}$ & $\begin{array}{l}0 \% \\
50 \% \\
50 \%\end{array}$ \\
\hline & $\leqslant \frac{\frac{5}{2}}{\frac{0}{3}}$ & $\begin{array}{l}\text { Low } \\
\text { Medium } \\
\text { High }\end{array}$ & $\begin{array}{r}50 \% \\
37.5 \% \\
12.5 \%\end{array}$ & $\begin{array}{l}50 \% \\
25 \% \\
25 \%\end{array}$ & $\begin{array}{r}50 \% \\
50 \% \\
0 \%\end{array}$ \\
\hline
\end{tabular}

As regards the IIRF's understanding or usefulness for designing an IRep, the options of answers were also transformed into a sort of Likert scale in order to facilitate the analysis (see Appendix B).

An average score of 1.64 and a median of 2 out a maximum score of 3 in Table 5 show that, on average, the respondents consider that IIRF has a medium usefulness level when it comes to the preparation of an IRep. At the same time, the biggest percentages are found in the extreme values of the scale, emphasizing oposite results. On the one hand, $35 \%$ of the respondents (five persons) who are familiar with IR mostly at the medium level perceive the IIRF's dispozitions as being clear enough to be applied by any entity in explaining the value creation process. On the other hand, $29 \%$ of the respondents (four persons), mostly with a low level of IR knowledge, claim that the IIRF is completely unknown for them. In this percentage, there are included two null answers that were considered as unknown.

IIRF's dispozitions are considered to be generic for preparing an IRep, but helpful when taken into account along with the examples from the IIRC database by professionals belonging to each level of IR knowledge, all graduated of an economic master degree and all working in an entity that provides services. Also, the respondent that has an economic PhD considers that the IIRF is very usefull for 
the preparation of the IRep. This high level of usefulness is perceived by experts working in all the three fields considered for this research: production, services and public institution.

Table 5. The opinion of Romanian accountants and financial auditors regarding the IIRF's usefulness in designing an IRep

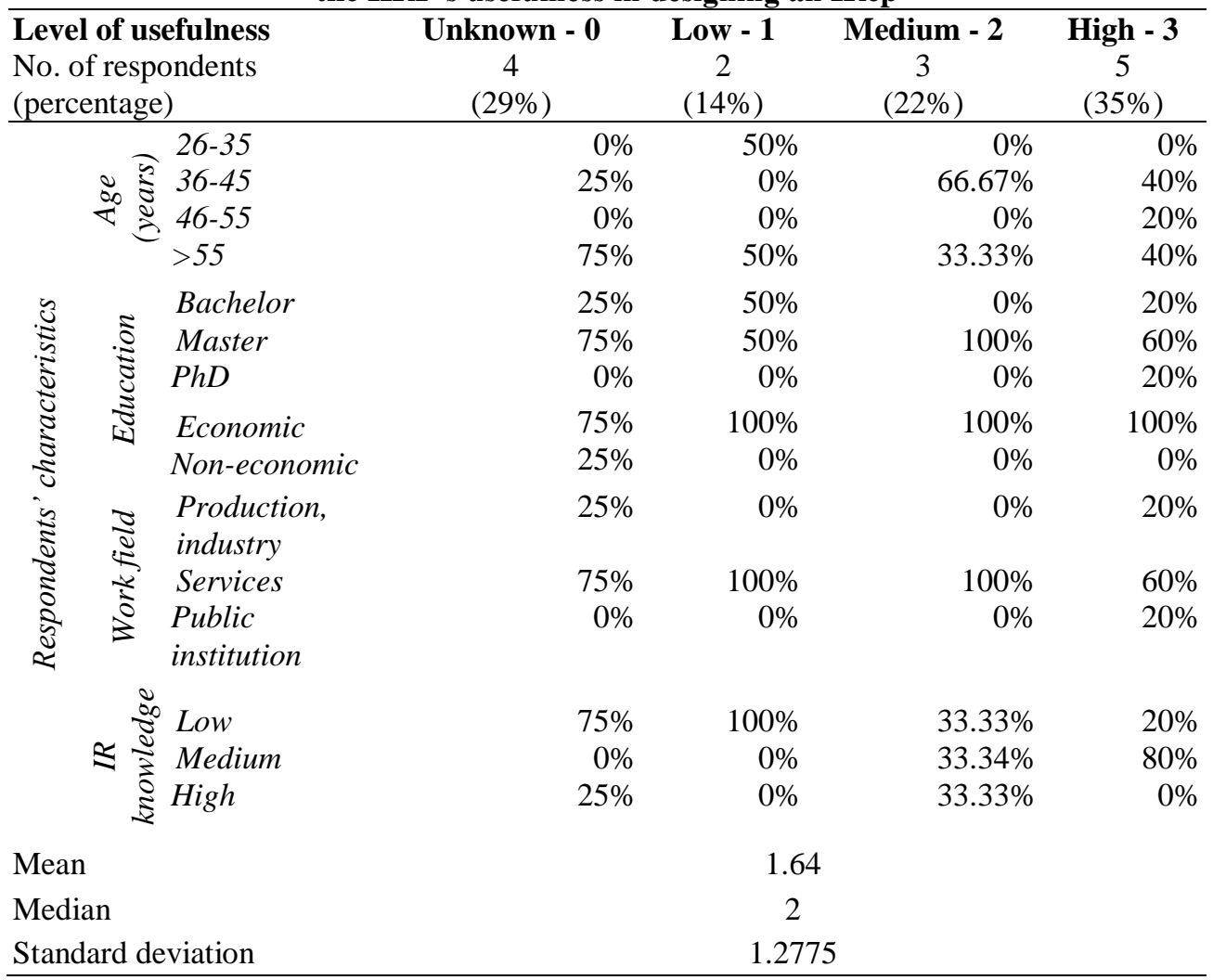

The Romanian accountants and financial auditors believe that the most important content element of an IRep (Table 6) are the risks and opportunities as regards both, financial and non-financial issues, and the outlook information. This option is shared across the sample; it is present in each category of age, each field of work, each type of education and each level of IR knowledge. 
Table 6. The most important content element of an IRep in the perspective of the Romanian accountants and financial auditors

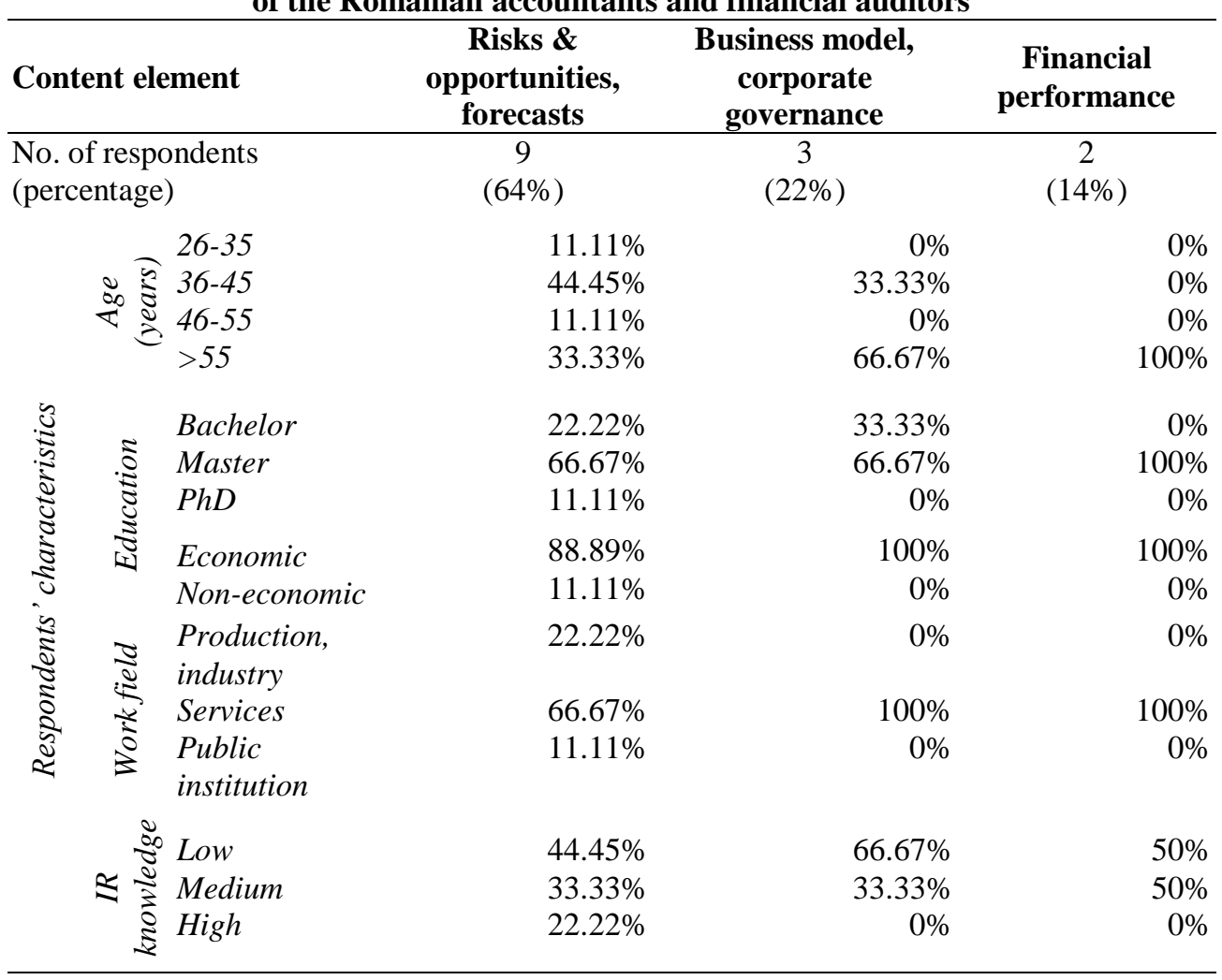

Contrary to the opinion of the professionals responsible with preparing an IRep who consider the strategy and the business model to be in the center of this document (Lai et al., 2018), the results of this study show that only $22 \%$ of the respondents see the business model and the corporate governance as the most important content elements.

Moreover and somehow surprinsingly, the third most important element is represented by the financial performance, aspect that could be associated to the fact that financial capital providers are the IIRC's target group for the IRep. Taken into account that the financial performance is the central concept of financial (annual) reporting, it is necessary and interesting to understand the context in which the accountants chose this option (level of IR knowledge and IRep's target user - there should be a link between the main element of a report and its targeted reader). Although both professionals that chose this option are over 55 years old, have an economic master degree and work in an entity that provides services, their contexts differ: while respondent number two is familiar with $I R$ at a medium level and considers that the community is the main user of the information existent in an 
IRep, the respondent number 10 has a low level of IR knowledge and perceives the managers and the investors as target user of IRep's content.

Withal, $78.57 \%$ of the respondents consider that an IRep's length should be less than 50 pages. This result reflects a small value, if taken into account the length of the reports that are usually awarded as excellent (e.g. EY Excellence in IR Awards) which often exceed 100 pages. It may also be due to the fact that only two experts had access to an actual IRep in order to observe its structure and volume; however, one of the respondents with a high level of IR knowledge considers that an IRep should have between 50 and 100 pages. The same opinion was shared by two respondents who are familiar with IR at a medium level.

The task of actually preparing the IRep should belong to the entity's financial department, regardless of the number and qualification of those who give an opinion on the part of the report concerning their activity. As it can be observed in Table 7, half of the respondents that are familiar with the IR concept believe that each department of the company should hand over a part of the final report that describes its performance to the financial one, which in turn will be in charge with the final format of the document. This option was chosen by professionals considered to have each of the three levels of IR knowledge and with ages over 36 years. Among the motivations for this choice, it can be found the idea that the financial department of an entity it is usually responsible with preparing the entity's reports (respondent number seven) and also with providing the last validation of such documents (respondent number 12). At the same time, respondent number nine which is the general manager of a firm providing services, graduated of a non-economic master degree and possessor of a high level of IR knowledge states that, based on its professional experience, this type of approach is oftenly used in multinational companies.

However, $36 \%$ of the respondents believe that the IRep should be prepared by a team formed by persons with different qualifications, depending on the specific of each entity. This allows a better knowledge of the company (respondent number two) and builds a transparent and comprehensive image (respondent number five) by providing information known only by the persons who do a certain activity within the company (respondents one, five and eight). The option was also chosen by the youngest respondent (with a low level of IR knowledge) which is an interesting fact taking into account that this professional accountant should be more open to changes in the traditional process of report's preparation and accept that this team is the most desirable IRep preparer. 
Table 7. The IRep's preparers in the opinion of Romanian accounting professionals

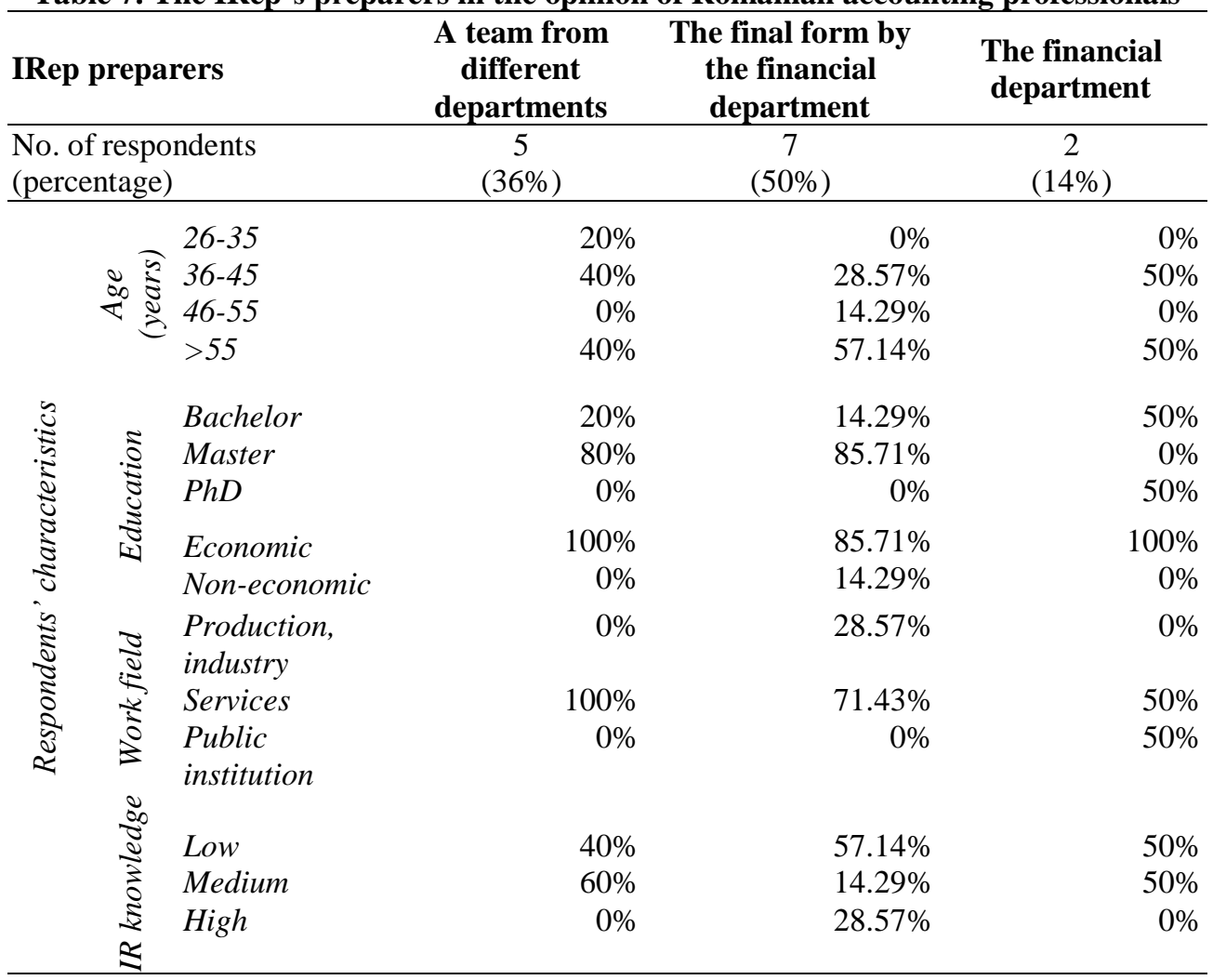

Furthermore, two respondents consider that the responsibility of preparing an IRep belongs entirely to the financial department. This is not very surprising because, as it was seen in introduction, accountants are expected to be more involved in nonfinancial reporting (IR included) due to their access to data (Egan \& Tweedie, 2018). Although these two experts agreed as regards the IRep preparer, the only thing that have in common is represented by the 10 years of work experience. For instance, while respondent number four has only an economic bachelor degree, works in services and does not know the characteritsics of IR (low level of knowledge), respondent number 18 has an economic $\mathrm{PhD}$, works in a public institution and is familiar only with the literature about IR (medium level of knowledge). Respondent number four believes that this decision belongs to the management team which will certainly direct the task of preparing the IRep to the financial department, that the main content element of this document is the business model and its target users are the managers and/or the investors. On the other hand, respondent number 18 considers that the IRep should focus on risks and opportunities and outlook information and that the content of this document is of financial institutions' interest. 


\section{Discussion and conclusions}

This study aimed to present the perspective of Romanian chartered accountants and financial auditors on IR in order to see if accounting professionals are prepared to face the challenges of IR. In Romania, this practice it is not implemented. As mentioned before, the IIRC database with examples of integrated reports does not include any Romanian company and only 42 Romanian entities publish reports according to GRI standards. Despite the fact that the literature promotes the existence of a team of persons with different qualifications that should participate in the preparation of an IRep, this study investigates the perspectives of the professionals who are responsible for the current reporting and could play an important role in the IR process in the future. In addition, the accountants are considered to be in the front line when it comes to the evolution of non-financial reporting.

As explained in the introduction, Romania represents an interesting setting as regards the objective of this study for three reasons. First, unlike the focus on Western Europe found in previous studies, this paper presents the perspective of an EU member state, but from Eastern Europe. Second, Romania is considered a developing economy where IR has potential to be implemented. Third, its communist history allows knowing how a phenomenon built in Western Europe is perceived by financial experts with an education framed in Eastern Europe, in the communist period. In this regard, it should be noted that half of the respondents are over 55 years old. Moreover, although many papers written by Romanian authors debate the subject of IR (see section 3.1), only one of them (Sofian, 2016) has the research based in the Romanian space and on Romanian companies.

\section{General results}

Based on this research, two aspects can be formulated. First, the low response rate may suggest that Romanian accountants and financial auditors are not very cooperative about such initiatives. In order to outline a general picture, the questionnaire uses mostly closed questions (with two or more options for answer); therefore, the average time calculated to complete it was quite short (about 10 minutes). Moreover, the whole process was online: it was build in Google Forms and sent via e-mail; thus, the respondents could have answered quickly and comfortably. Second, the answers obtained on this subject emphasized a reduced level of knowledge of IR and also a majority of perspectives deeply influenced by the traditional profession's judgement. Hence, the Romanian chartered accountants and financial auditors are familiarized with the idea of IR, mainly because they had heard about IR in their work environment, but they do not know its characteristics. Then, a medium level of knowledge is due to the reading of the literature in the field. The respondents for whom the concept of IR is completely unknown are over 36 years old, have an economic bachelor degree and work for an entity that 
provides services. Although all the respondents have over 10 years of work experience, some results concur with previous research and some results offer a new and different perspective on the established objective.

The IR definitions provided by the respondents that are familiar (at some extent) with IR converge in notions such as: one report, the mix of financial and nonfinancial information with the purpose of improving the investors' decision-taking process as the main users of an IRep. Similar to the financial statements, this practice is associated with the reflection of a true and fair image and, at the same time, it could be mandatory for certain types of entities or it could remain voluntary. In accordance with the results of previous studies, this research shows that a better reputation is perceived as the main expected benefit of IR.

Most of the respondents consider that the IRep is necessary and that its preparation in its final form it is up to the financial department or, to a lesser extent, to a multidisciplinary team. In general, the IIRF is perceived as being clear in this regard, but the length of an IRep should be of maximum 50 pages. Contrary to previous research, the business model it is not seen as the most important content element of this report, but the risks, opportunities and the outlook information.

\section{Cross-sectional profiles}

The professionals considered to have a high level of IR knowledge are either between 36 and 45 years old or over 55 years old, have a master degree, one in an economic area and one in another profile and work for a company that provides services. They chose a 'fair image' as concept developed by IR, observed only external benefits and consider that the IRep's target group is represented by investors and/or managers or by community and/or government. One of them is not familiar with the IIRF and the other considers that this framework provides a medium level of usefulness when it comes to the preparation of an IRep. They also consider the risks and opportunities and the outlook information to be the most important content elements of an IRep and that the financial department within an entity should be responsible with the final format of this document.

The accountants considered to have a medium level of IR knowledge are over 36 years old, have either an economic or a non-economic master degree or an economic $\mathrm{PhD}$ and work mostly in services, but also in a production entity or in a public institution. Although the majority supports the 'fair image' concept as representative for IR, they also choose creative accounting or impression management for the same purpose. They consider that the IIRF provides a medium or a high level of usefulness for designing an IRep and split their option for the IRep's preparers between the financial department (either, alone or just for the final form of the document) and a multidisciplinary team. The identified IR benefits are both, internal and external and the perceived target group is also divided between managers and investors, community and government and financial institutions. As 
regards the main content element, although there is a focus on risks and opportunities and forecasts, they also chose business model and corporate governance and financial performance.

The respondents considered to have a low level of IR knowledge are either between 26 and 45 years old or over 55 years old, have an economic bachelor or master degree and work for a production entity or for one that provides services. There was found a majority for the representative concept of 'fair image', but there were also chosen options like impression management and questionable quality of information. The identified benefits of IR include a better knowledge of the entity and of the roles of its members and a better reputation. As regards the IIRF, its usefulness for preparing an IRep is either low, medium or high, either its dispozitions are unknown. Both, the target group of users and the main content element of an IRep are split between all the available options and, although the final format of this document should be the responsibility of the financial department, its preparation could be also made by a multidisciplinary team or only by the financial department.

Since there are two outstanding respondents (as regards age and education), it was considered interesting to outline their profiles in the following rows. The youngest respondent considered that the information available in the IRep is of questionable quality and that the IIRF is not very usefull when it comes to supporting the preparation of this document. On the other hand, the respondent that has an economic $\mathrm{PhD}$ did not provide a concept to be associated to IR, but perceived a high level of usefulness for the IIRF in the design of an IRep. Although both of these respondents consider the risks and opportunities and the outlook information as being the most important content elements of an IRep, the chosen target group differs: the youngest respondent claims it is represented by the investors and/or managers and the respondent with a PhD supports the financial institutions. At the same time, both of them agree about the existence of external benefits, but the respondent with a $\mathrm{PhD}$ also acknowledges the internal ones. Another difference between these two professionals arises from the opinion regarding the responsible with the IRep preparation: the respondent with the economic $\mathrm{PhD}$ considers that this responsibility belongs exclusively to the financial department, while the youngest respondent supports a multidisciplinary team.

\section{Conclusion and contribution}

In conclusion, this study shows that the Romanian accountants and financial auditors do not know very well the concept of IR, but consider that they are entitled to prepare the IRep. Hence, more education is needed among the accounting professionals, as well as a better integration of the concept of IR in the organizational culture of Romanian entities. From the respondents' point of view, Romanian companies are neither prepared, nor in need to implement IR, mainly because of the lack of financial and time resources involved in this process. 
Therefore, this study contributes to the existent literature through the approach it proposes - the Romanian context: Eastern European state, member of the EU, but with communist history and without experience in the area of IR - along with the focus on a less explored, but important category of potential participants in the implementation of IR and in the preparation of an IRep - the accounting professionals.

\section{Limitations and future directions of research}

Among the main limitations of this study, it can be found the reduced number of responses received. This limitation can be adressesed through the existing need for professional accountants' involvement in the evolution of non-financial reporting (IR included) detailed in the introduction. Furthermore, an ACCA study shows that these experts possess the ability to operate in complex markets (i.e., developing countries such as Romania) where sustainable development issues are present in the center of value creation (ACCA, 2017). Hence, their opinion matters and these results show an interesting and important view of the IR phenomenon. At the same time, an alarm signal it is raised both, in terms of accounting profession's reluctance to get involved in such research initiatives and as regards the IR potential of development in Romania.

Another limitation can be considered the focus only on chartered accountants and financial auditors. In addition, both, previous literature (McNally \& Maroun, 2018) and the results of this study promote the idea that the management decides about the preparation of an IRep; thus, it is possible that adding the managers' perspective would offer a more complete view on the phenomenon and would also allow comparisons between different stakeholders. Moreover, another future direction of research can be represented by the analysis of the level of education provided in Romanian universities in the area of IR (how many institutions mention this subject in their bachelor or master programs, the qualification of the teachers in this regard etc.).

This paper started from the idea the IR involves interaction between human beings: from the preparation for change, to its implementation and acceptance, to the publication of the IRep and to the use of the information provided in that report in order to take decisions. In other words, human being relates to employees, managers, shareholders, investors, analysts, auditors etc. Stakeholders' perspectives are usually different from the results of the studies based on the analysis of the IRep or on the links between company's performance indicators and capital market benchmarks, for instance. This study emphasized the fact that, in Romania, the concept of IR it is not well known among accounting professionals and that Romanian firms are not yet prepared for its implementation. Additional research is needed to learn more about the potential for implementing this practice in Romania, but also in other Eastern European countries. 


\section{References}

ACCA (2013) "Understanding investors: directions for corporate reporting", Association of Chartered Certified Accountants, available online at: https://www.accaglobal.com/content/dam/acca/global/PDFtechnical/financial-reporting/pol-afbui02.pdf [accessed on 25 January 2019]

ACCA (2017) "The Sustainable Development Goals: redefinig context, risk and opportunity", Association of Chartered Certified Accountants, available online at: https://www.accaglobal.com/hk/en/professional-insights/globalprofession/the-sustainable-development-goals.html [accessed on 21 February 2021]

Adams, C. (2014) "New research finds benefits to companies doing integrated reporting", available online at: https://drcaroladams.net/new-research-findsbenefits-to-companies-doing-integratedreporting/ [accessed on 16 March 2019]

Adams, C. (2015) "The International Integrated Reporting Council: A call to action", Critical Perspectives on Accounting, vol. 27: 23-28

Adhariani, D., \& De Villiers, C. (2019) "Integrated reporting: perspectives of corporate report preparers and other stakeholders", Sustainability Accounting, Management and Policy Journal, vol. 10(1): 126-156

Ahmed Haji, A., \& Mahboob Hossain, D. M. (2016) "Exploring the implications of integrated reporting on organisational reporting practice", Qualitative Research in Accounting \& Management, vol. 13(4): 415-444

Ambasada Sustenabilitatii (2021) "Despre Ambasada Sustenabilitatii in Romania", available online at: https://ambasadasustenabilitatii.ro/despre/ [accessed on 21 February 2021]

Atkins, J., \& Maroun, W. (2015) "Integrated reporting in South Africa in 2012. Perspectives from South African institutional investors", Meditari Accountancy Research, vol. 23(2): 197-221

Avram, V., Calu, D. A., Dumitru, V. F., Dumitru, M., Glăvan, M. E., \& Jinga, G. (2018) "The institutionalization of the consistency and comparability principle in the European Companies", Energies, vol. 11, 3456

Black Sun (2014) "Realizing the benefits: The impact of Integrated Reporting", Black Sun Plc, available online at: http://integratedreporting.org/ wpcontent/uploads/2014/09/IIRC.Black_.Sun_.Research.IR_.Impact.Single. pages.18.9.14.pdf [accessed on 25 January 2019]

Burke, J. J., \& Clark, C. E. (2016) "The business case for integrated reporting: Insights from leading practitioners, regulators, and academics", Business Horizons, vol. 59(3): 273-283

Capotă, V., Popa, F., \& Ghinescu, C. (2006) Marketingul afacerii: manual pentru clasa a XI-a și a XII-a rută progresivă. București: Editura Akademos Art

Caraiani, C., Lungu, C. I., Bratu, A., \& Dascălu, C. (2018) "Exploring the perspectives of integrated reporting for future research opportunities", Accounting and Management Information Systems, vol. 17(4): 532-565 
Chaidali, P., \& Jones, M. J. (2017) "It's a matter of trust: Exploring the perceptions of Integrated Reporting preparers", Critical Perspectives on Accounting, vol. 48: $1-20$

Dragu, I.-M., \& Tiron-Tudor, A. (2013) "The Integrated Reporting Initiative from an institutional perspective: emergent factors", Procedia - Social and Behavioral Sciences, vol. 92: 275-279

Dragu, I., Tiron-Tudor, A. (2014) "Research agenda on integrated reporting: new emergent theory and practice", Procedia - Economics and Finance, vol. 15: 221-227

Du Toit, E. (2017) "The readability of integrated reports", Meditari Accountancy Research, vol. 25(4): 629-653

Dumitru, M., \& Gușe, R. (2016) "Assurance of integrated reports: the state of the art", Audit Financiar, vol. XIV(2/134): 172-180

Dumitru, M., \& Gușe, R. G. (2017) "The Legitimacy of the International Integrated Reporting Council”, Accounting and Management Information Systems, vol. 16(1): $30-58$

Dumitru, M., \& Jinga, G. (2015) "Integrated reporting practice for sustainable business: a case study", Audit Financiar, vol. XIII(7/127): 40-48

Dumitru, M., \& Sofian, I. (2017) "Integrated reporting in scientific publications presentation of the state of the art", IFRS: Global Rules and Local Use Proceedings of the $5^{\text {th }}$ International Scientific Conference, October 20, 2017 , Prague: Anglo-American University, pp. 7-27

Dumitru, M., Guşe, R. G., Feleagă, L., Mangiuc, D. M., \& Feldioreanu, A. I. (2015) "Marketing communications of value creation in sustainable organizations. the practice of integrated reports", Amfiteatru Economic, vol. 17(40): 955-976

Eccles, R. G., \& Saltzman, D. (2011) "Achieving sustainability through integrated reporting", Stanford Social Innovation Review, Summer: 56-61

Egan, M., \& Tweedie, D. (2018) "A "green" accountant is difficult to find. Can accountants contribute to sustainability management initiatives?", Accounting, Auditing \& Accountability Journal, vol. 31(6): 1749-1773

EY (2013) "2013 six growing trends in corporate sustainability", Ernst \& Young, available online at: https://www.ey.com/Publication/vwLUAssets/Six _ growing_trends_in_corporate_sustainability_2013/\$FILE/Six_growing_tren ds_in_corporate_sustainability_2013.pdf [accessed on 16 March 2019]

Feng, T., Cummings, L., \& Tweedie, D. (2017) "Exploring integrated thinking in integrated reporting - an exploratory study in Australia", Journal of Intellectual Capital, vol. 18(2): 330-353

Higgins, C., Stubbs, W., \& Love, T. (2014) "Walking the talk(s): Organisational narratives of integrated reporting", Accounting, Auditing \& Accountability Journal, vol. 27(7): 1090-1119

IFAC (2012) "Investor demand for environmental, social, and governance disclosures. Implications for professional accountants in business", International Federation of Accountants, available online at: https://www.ifac.org/system/files/publications/files/Investor-Demand-for- 
Environmental-Social-and-Governance-Disclosures-Implications-for-

Professional-Accountants-in-Business.pdf [accesed on 22 February 2021]

IMA (2016) "Integrated Reporting. Statement on Management Accounting", Institute of Management Accountants, available online at: https://www.imanet.org/insights-andtrends/external-reporting-anddisclosure-management/integrated-reporting?ssopc=1 [accessed on 21 April 2019]

Krzus, M. P. (2011) “Integrated Reporting: if not now, when?", IRZ, vol. 6: 271276

Kuasirikun N. (2005) "Attitudes to the development and implementation of social and environmental accounting in Thailand", Critical Perspectives on Accounting, vol. 16: 1035-1057

Kuzina, R. W. (2014) "Integrated reporting as a mechanism of increasing business value", Actual Problems of Economics, vol. 8(158): 385-392

Kwakye, T. O., Welbeck, E. E., Owusu, G. M. Y., \& Anokye, F. K. (2018) "Determinants of intention to engage in Sustainability Accounting \& Reporting (SAR): the perspective of professional accountants", International Journal of Corporate Social Responsibility, vol. 3:11

Lai, A., Melloni, G., \& Stacchezzini, R. (2018) "Integrated reporting and narrative accountability: the role of preparers", Accounting, Auditing \& Accountability Journal, vol. 31(5): 1381-1405

Lapteș, R., \& Sofian, I. (2016) "A new dimension of the entities' financial reporting: Integrated Reporting", Bulletin of the Transilvania University Braşov, Series V: Economic Sciences, vol. 9-58(2): 239-250

Lapteş, R., \& Sofian, I. (2017) "Aspects regarding the adoption and development of integrated reporting practices", Bulletin of the Transilvania University Brașov, Series V: Economic Sciences, vol. 10-59(2): 187-200

Maas, K., Schaltegger, S., \& Crutzen, N. (2016) "Integrating corporate sustainability assessment, management accounting, control, and reporting", Journal of Cleaner Production, vol. 136: 237-248

Malsch, B. (2013) "Politicizing the expertise of the accounting industry in the realm of corporate social responsibility", Accounting, Organizations and Society, vol. 38: 149-168

Maroun, W. (2017) "Assuring the integrated report: Insights and recommendations from auditors and preparers", The British Accounting Review, vol. 49(3): 329-346

McNally, M.-A., \& Maroun, W. (2018) "It is not always bad news: Illustrating the potential of integrated reporting using a case study in the eco-tourism industry", Accounting, Auditing \& Accountability Journal, vol. 31(5): $1319-1348$

McNally, M.-A., Cerbone, D., \& Maroun, W. (2017) "Exploring the challenges of preparing an integrated report", Meditari Accountancy Research, vol. 25(4): 481-504 
Melloni, G., Caglio, A., \& Perego, P. (2017) "Saying more with less? Disclosure conciseness, completeness and balance in Integrated Reports", Journal of Accounting and Public Policy, vol. 36(3): 220-238

Morros, J. (2016) "The integrated reporting: A presentation of the current state of art and aspects of integrated reporting that need further development", Intangible Capital, vol. 12(1): 336-356

Oprișor, T. (2015) "Contributions to an improved framework for integrated reporting", Accounting and Management Information Systems, vol. 14(3): 483-507

Paolucci, G., \& Cerioni, E. (2017) "Integrated Reporting and Italian Companies: An Empirical Investigation", International Journal of Business and Management, vol. 12(9): 221-230

Perego, P., Kennedy, S., \& Whiteman, G. (2016) "A lot of icing but little cake? Taking integrated reporting forward", Journal of Cleaner Production, vol. 136: 53-64

Slack, R., \& Tsalavoutas, I. (2018) "Integrated reporting decision usefulness: Mainstream equity market views", Accounting Forum, vol. 42(2): 184-198

Sofian, I., \& Dumitru, M. (2017) "The compliance of the integrated reports issued by European financial companies with the International Integrated Reporting Framework", Sustainability, vol. 9(8): 1-16

Sofian, I. (2016) "The adoption of integrated reporting principles by the Romanian companies listed at the Bucharest Stock Exchange", Audit Financiar, vol. XIV(12/144): 1335-1348

Sofian (Neacşu), I. (2017) "Approaching value creation from an integrated reporting perspective", IFRS: Global Rules and Local Use Proceedings of the $6^{\text {th }}$ International Scientific Conference, October 11-12, 2018, Prague: Anglo-American University, pp. 247-260

Sofian (Neacșu), I. (2019) "Does an improved type of reporting lead to a better financial performance", Accounting and Management Information Systems, vol. 18(1): 73-100

Stacchezzini, R., Melloni, G., \& Lai, A. (2016) "Sustainability management and reporting: the role of integrated reporting for communicating corporate sustainability management", Journal of Cleaner Production, vol. 136: $102-110$

Steyn, M. (2014) "Organisational benefts and implementation challenges of mandatory integrated reporting", Sustainability Accounting, Management and Policy Journal, vol. 5(4): 476-503

Stubbs, W., \& Higgins, C. (2014) "Integrated Reporting and internal mechanisms of change", Accounting, Auditing \& Accountability Journal, vol. 27(7): 1068-1089

Stubbs, W., \& Higgins, C. (2018) "Stakeholders' perspectives on the role of regulatory reform in integrated reporting", Journal of Business Ethics, vol. 147(3): 489-508

Stubbs, W., Higgins, C., \& Milne, M. (2016) "An exploration of the information needs of selected stakeholders of integrated reporting", CPA Australia, available online at: https://www.cpaaustralia.com.au/ /media/corporate/ 
allfiles/document/professionalresources/sustainability/report-explorationstakeholder-needs-integrated-reporting.pdf?la=en [accessed on 19 February 2018]

Sustainability disclosure database (2021) Search by filter Country: Romania, available online at: https://database.globalreporting.org/search/ [accessed on 6 January 2021]

Tiron-Tudor, A., \& Dragu, I. M. (2014) "From sustainability to integrated reporting - the political perspective of institutional theory", Studia Universitatis Babeș-Bolyai Oeconomica, vol. 59(2): 20-33

Turturea, M. (2015) "Social and environmental reporting as a part of the integrated reporting", Acta Universitatis Agriculturae et Silviculturae Mendelianae Brunensis, vol. 63(6): 2161-2169

Van Bommel, K. (2014) "Towards a legitimate compromise?", Accounting, Auditing \& Accountability Journal, vol. 27(7): 1157-1189

\section{Appendix A - Brief presentation of the questionnaire}

\begin{tabular}{|l|l|}
\hline \multicolumn{1}{|c|}{ Question no. } & \multicolumn{1}{|c|}{ Type of question } \\
\hline $\begin{array}{l}\text { 1. How familiar are you with the concept of IR? Please select the } \\
\text { situation or situations that characterize you: }\end{array}$ & Multiple choice \\
\hline 2. How would you define the concept of IR? & Open \\
\hline $\begin{array}{l}\text { 3. Based on your professional judgement and taken into account } \\
\text { the existence of other types of non-financial reporting } \\
\text { (sustainability reporting, CSR reporting, etc.), do you consider } \\
\text { that an IRep is necessary? }\end{array}$ & Closed - single choice \\
\hline 4. Motivate the choice made on the previous question: & Open \\
\hline $\begin{array}{l}\text { 5. From the perspective of your status (information producer), } \\
\text { how do you characterize the information presented in the IIRF? }\end{array}$ & $\begin{array}{l}\text { Closed - single choice } \\
+ \text { 'other' }\end{array}$ \\
\hline $\begin{array}{l}\text { 6. What do you think it is the main category of users to whom an } \\
\text { IRep addresses to? }\end{array}$ & Closed - single choice \\
\hline \begin{tabular}{l} 
7. Who do you think it should prepare the IRep? \\
\hline $\begin{array}{l}\text { 8. Explain briefly the reasons why you opted for a particular } \\
\text { option on the previous question: }\end{array}$
\end{tabular} & $\begin{array}{l}\text { Closed - single choice } \\
+ \text { 'other' }\end{array}$ \\
\hline $\begin{array}{l}\text { 9. What benefits do you think IR has or would have for the entity } \\
\text { you belong to? }\end{array}$ & Multiple choice \\
\hline $\begin{array}{l}\text { 10. What do you think about the resources needed to prepare an } \\
\text { IRep (especially time and financial)? Do you consider that the } \\
\text { entity you belong to has the necessary resources for this practice? } \\
\text { Please detail. }\end{array}$ & Open \\
\hline $\begin{array}{l}\text { 11. What concept do you think the practice of IR develops? } \\
\text { 12. From the perspective of the status you have (information } \\
\text { producer), what do you consider to be the optimal length of an } \\
\text { IRep? }\end{array}$ & Closed - single choice \\
\hline
\end{tabular}




\begin{tabular}{l|l|}
$\begin{array}{l}\text { 13. From the perspective of your status (information producer), } \\
\text { what component element do you think an IRep should focus on? }\end{array}$ & Closed - single choice \\
\hline $\begin{array}{l}\text { 14. Do you consider that IR should be mandatory? Justify. } \\
\text { 15. Your age is between: }\end{array}$ & Open \\
\hline 16. The last category of studies completed by you is: & Closed - single choice \\
\hline 17. Your hierarchical position in the entity where you work is: & $\begin{array}{l}\text { Closed - single choice } \\
+ \text { 'other' }\end{array}$ \\
\hline 18. In what field operates the entity you work for? & $\begin{array}{l}\text { Closed - single choice } \\
+ \text { 'other' }\end{array}$ \\
\hline 19. Your work experience is (years): & Closed - single choice \\
\hline
\end{tabular}

Source: author's compilation, 2021

\section{Appendix B - Coding procedure}

\begin{tabular}{|c|c|}
\hline $\mathbf{Q u}$ & Co \\
\hline $\begin{array}{l}\text { Question } 1 \text { [multiple choice]: How familiar are you with the } \\
\text { concept of IR? Please select the situation or situations that } \\
\text { characterize you: } \\
\text { a. I have heard about this type of reporting, but I do not } \\
\text { know very much about its characteristics } \\
\text { b. I have read about IR in papers from national and/or } \\
\text { international journals } \\
\text { c. I had access to or I work with integrated reports } \\
\text { d. The concept of IR it is completely unknown for me }\end{array}$ & $\begin{array}{l}\text { el of IR knowledge } \\
\text { ltiple choice]: } \\
\text { a. Low - } 1 \\
\text { b. Medium - } 2 \\
\text { c. High - } 3 \\
\text { d. Unknown - } 0\end{array}$ \\
\hline $\begin{array}{l}\text { Question } 5 \text { [single choice]: From the perspective of your status } \\
\text { (information producer), how do you characterize the } \\
\text { information presented in the IIRF? } \\
\text { a. Information is generic, unclear, hard to apply when } \\
\text { designing an IRep and influences users' expectations } \\
\text { when reading the report } \\
\text { b. Information is generic, but along with the examples } \\
\text { from the IIRC's database, is easier to apply and/or } \\
\text { visualize in practice } \\
\text { c. Information is clear, indicating the exact manner in } \\
\text { which the value creation process should be reflected } \\
\text { by any entity, regardless of its industry } \\
\text { d. Other (please give details) }\end{array}$ & $\begin{array}{l}\text { el of IIRF usefulness } \\
\text { gle choice]: } \\
\text { a. Low - } 1 \\
\text { b. Medium - } 2 \\
\text { c. High - } 3 \\
\text { d. Unknown - 0 (all } \\
\text { answers indicated } \\
\text { that the } \\
\text { respondent is not } \\
\text { familiar with the } \\
\text { IIRF) }\end{array}$ \\
\hline $\begin{array}{l}\text { Question } 6 \text { [single choice]: What do you think it is the main } \\
\text { category of users to whom an IRep addresses to? } \\
\text { a. Managers and/or investors } \\
\text { b. Community (general public), government } \\
\text { c. NGOs related to human rights and environment } \\
\text { protection } \\
\text { d. Financial institutions (banks, insurance entities) }\end{array}$ & $\begin{array}{l}\text { IRep target users [single } \\
\text { choice]: } \\
\text { a. } \quad \begin{array}{l}\text { Managers, } \\
\text { investors }\end{array} \\
\text { b. Community, } \\
\text { government } \\
\text { No codification (zero }\end{array}$ \\
\hline
\end{tabular}




\begin{tabular}{|c|c|}
\hline Question and options of answer & Coding (Likert scale) \\
\hline & \begin{tabular}{|cl} 
answers on this option) \\
c. & $\begin{array}{l}\text { Financial } \\
\text { institutions }\end{array}$ \\
\end{tabular} \\
\hline $\begin{array}{l}\text { Question } 7 \text { [single choice]: Who do you think it should prepare } \\
\text { the IRep? } \\
\text { a. The financial department } \\
\text { b. A team formed by people with different qualifications: } \\
\text { finance, marketing, production, legal, sales, } \\
\text { acquisitions, management etc. } \\
\text { c. Each department should hand over to the financial one } \\
\text { a part of the final report related to its activity and the } \\
\text { financial department should provide the final format of } \\
\text { the report } \\
\text { d. Other (please give details) }\end{array}$ & \begin{tabular}{|rl} 
IRep preparers [single \\
choice]: \\
a. & Financial \\
& department \\
b. & Team from \\
& different \\
& departments \\
c. & Final form by \\
& financial \\
& department \\
& \\
No codification (zero \\
answers on this option)
\end{tabular} \\
\hline $\begin{array}{l}\text { Question } 9 \text { [multiple choice]: What benefits do you think IR } \\
\text { has or would have for the entity you belong to? } \\
\text { a. A better internal communication } \\
\text { b. A better knowledge of the entity's activity and of the } \\
\text { roles of its members } \\
\text { c. A better visibility externally, in the business } \\
\text { environment and (if case) on the financial markets } \\
\text { d. I do not consider that it will bring additional benefits } \\
\text { from the ones that current reporting brings }\end{array}$ & 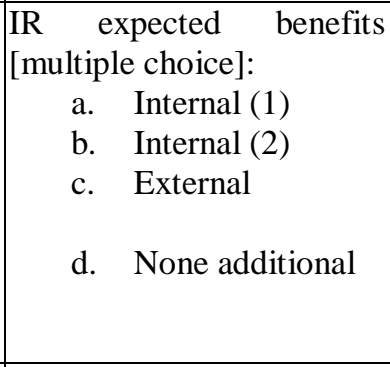 \\
\hline $\begin{array}{l}\text { Question } 13 \text { [single choice]: From the perspective of your status } \\
\text { (information producer), what component element do you think } \\
\text { an IRep should focus on? } \\
\text { a. Business model, corporate governance } \\
\text { b. Financial performance } \\
\text { c. Social and environmental performance } \\
\text { d. Risks \& opportunities, forecasts in differents areas } \\
\text { (financial, environmental, social, technological etc.) }\end{array}$ & $\begin{array}{l}\text { Key component element } \\
\text { [single choice]: } \\
\text { a. } \quad \begin{array}{l}\text { Business model, } \\
\text { corporate }\end{array} \\
\text { governance } \\
\text { b. } \quad \text { Financial } \\
\text { performance } \\
\text { No codification (zero } \\
\text { answers on this option) } \\
\text { c. } \quad \text { Risks \& } \\
\quad \text { opportunities, } \\
\text { forecasts }\end{array}$ \\
\hline
\end{tabular}

